\title{
Positioning an academic literacies framework in an EAP context: case study of a university Pre-sessional course
}

\author{
Paul Breen \\ University of Westminster, UK
}

\begin{abstract}
Historically, there has been a strong element of crossover between English for Academic Purposes (EAP) and academic literacies approaches, as originally conceptualised by Lea and Street (1998). However, a recurring cause of concern for the latter has been its perceived lack of focus on pedagogy, with greater emphasis on construction of text (Lea, 2004). Lillis (2003) highlights another concern being the lack of 'a design frame' (Kress, 2000) which can harness synergy between theory and practice. As such, the strength of academic literacy from a theoretical perspective can simultaneously be an Achilles heel in its practical pedagogic application. Consequently, examples of sustained academic literacies approaches in practice are rare. This paper thus argues for EAP acting as a fulcrum between theory and practice and provides one instance of enacting academic literacies approaches in the practical context of a Pre-sessional course in a post-92 university. Therein academic literacies approaches have shaped the design and delivery of an EAP curriculum. Through presenting a case study of this story, I hope to provide one 'exemplar' (Shulman, 1986) of integrating pedagogic practice and theory to serve as a model for the future. In doing so, academic literacies can better meet both the practical and theoretical demands of $21^{\text {st }}$ century teaching, learning and educational development.
\end{abstract}

Keywords: academic literacies; English for Academic Purposes; pedagogic research; case study research; Pre-sessional courses.

\section{Background relationship of EAP and academic literacy}

Gimenez and Thomas (2015, p.30) draw on the work of Hyland and Hamp-Lyons (2002, p.4) to suggest that despite having developed in 'quite different socio-political contexts' 
EAP and academic literacies approaches 'both aspire to provide students with a more successful educational experience.' Academic literacy as a model is focused on the empowerment of individuals through finding their place within their disciplinary community and understanding the social practices of those disciplines.

Academic literacy is not simply about the 'acquisition of a particular set of cognitive skills, which once acquired can be put to use unproblematically in any new context' (Street (1984), Gee (1990), and Barton (1994), cited by Lea, 2004, p.740). The cultural and social practices of each discipline and context is also markedly different (Lea, 2004, p.740). Within EAP there has been a recognition of this and a shift away from generic skills to concentration on the needs of students within specific disciplines. Jones and Lea (2008) further highlight the natural connection between EAP and academic literacies approaches through their innate emphasis on text analysis and text production alongside articulation of stance. Despite this, Wingate (2012, p.3) argues that 'normative' approaches in traditional EAP can be out of synch with academic literacies' 'oppositional frame' (Lillis and Scott, 2007, p.11).

Indeed, academic literacy has been moulded around a shift away from 'academic socialisation' and 'study skills' models of delivering and designing EAP courses (Lea and Street, 1998, p.158). However, circumstances often necessitate that EAP courses are remedial and skills-driven due to students having low levels of proficiency in the English language to begin with. At the outset of such courses, students' language is rarely sophisticated enough to achieve what Gimenez and Thomas (2015) describe as the sociopolitical dimension emphasised by academic literacies. The need to develop language proficiency therefore had to be given major consideration when designing this Presessional Academic English course for international students.

\section{EAP and the context of Pre-sessional courses}

Hamp-Lyons (2011, p.91) has described EAP as being a 'poor relation' of more 'specific' subjects in higher education. Others have spoken of it in similar ways. Healy $(2014$, p.1) speaks of the subject having a 'Cinderella status' whilst Breen (2018, pp.1-2) calls it a 'chameleon discipline' forever needing to adapt to the needs of others rather than finding 
its own identity. Unlike academic literacies approaches, there is no single framework for EAP teaching because courses are context-specific. In the case of Pre-sessionals, courses are largely designed around the language level of students and a particular university's entrance requirements balanced against the market-driven nature of $21^{\text {st }}$ century UK higher education (Turner, 2004).

Pre-sessional courses therefore occupy the unusual position of being a poor relation in some senses and a fatted calf on the other. Essentially these are 'sheltered courses' (Gilbert, 2013, p.119) that take place over the summer months prior to a September entrance point for international students who have failed to meet the necessary language requirements (Alexander et al, 2008). Such courses are further pushed to the margins of academia because they are generally seen as 'commodified, revenue-generating support activity' outside of the mainstream focus of the institutions in which they operate (Ding and Bruce, 2017, p.53). At the same time, there are strict checks and balances in place to ensure such courses are regulated and assessed properly. As a result of that, their design needs to meet the same quality assurance standards as all other courses within the UK higher education system.

\section{The Pre-sessional course in this study}

In the particular case of this study, the core Pre-sessional teaching was and still is delivered in a three month block of 23 hours per week. To satisfy university entrance requirements and visa regulations, students are tested in the four skills of reading, listening, writing and speaking. Previously, this course had been delivered in a manner more typical of English for Generic Academic Purposes rather than Specific Purposes (Gilbert, 2013; Blue, 1988). As such, it was largely remedial and not meeting the needs of specific disciplines despite this being an expectation of university departments. That caused a serious mismatch along the lines of Argyris and Schön's (1974) work on dichotomies between espoused theory and theory-in-action, as detailed in Donaghue (2003, p.345). To address this mismatch, the course needed to be more discipline-specific. The situation thus necessitated a theoretical underpinning that could be enacted in practice. 
Traditionally, many Pre-sessional courses have been shaped around the type of 'academic socialisation' and 'study skills' approaches that Lea and Street (1998, p.158) warn against. Through only focusing on these aspects, students might progress into the academy without being able to decipher the conventions of their disciplines in the critical way that Hyland and Hamp-Lyons (2002), Wingate (2012), and Gimenez and Thomas (2015) speak of. However, without these components, many of today's students will struggle and this is especially the case in an age of mass recruitment of international students.

Academic literacies was chosen as the fulcrum through which discipline-specificity could be leveraged on the Pre-sessional course. For this to happen, there had to be a practical as well as an ideological aspect (Lillis, 2003; Lea, 2004) and a realisation that academic literacy is not purely about a focus on discipline specific texts (Lillis and Scott, 2007). That was particularly important in a context where assessment on Pre-sessional courses must be benchmarked in some way to the United Kingdom Visa and Immigration (UKVI) authorities' stipulated standardised test - International English Language Testing System (IELTS).

To satisfy the criteria for this, we had to maintain a system of testing students in this way but we adapted the assessment in such a way that it more closely reflected the practices of disciplines. The programme of study was shaped around a 'backwards design' process which identifies learning outcomes first and then designs assessment as evidence of how those outcomes have been achieved (Wiggins and McTighe, 2005; Fink, 2007). This meant that the ultimate goal of the course was for students not just to complete a set of exams benchmarked to IELTS. Rather, they had to work towards the completion of a piece of research in their specific disciplines that after a period of scaffolding would lead to the submission of a 1500 word essay as their final writing assignment.

Similarly, a higher amount of authentic texts and interlinked, contextualised materials were introduced into the curriculum and the assessments (see appendix one for sample of curriculum design). Significantly too, for the purposes of theoretical underpinning, we redesigned the course around Lea and Street's own assertion that study skills, academic socialisation and academic literacies are not 'mutually exclusive' nor should be viewed in 'a simple linear time dimension' (1998, p.158). Students thus developed all three key 
aspects in synch, rather than progressively. Finally, as advocated in much of the literature, a digital literacy component was incorporated (Jones and Lea, 2008; Coiro et al, 2008; Gilbert, 2013.) Interactive approaches to teaching with technologies facilitated 'a deeper, more essential understanding and mastery of information technology for information processing, communication, and problem solving' (Koehler and Mishra, 2009, p.64).

Digital resources were adapted around a curriculum that reflected the social practices of the university and its disciplinary communities. The virtual learning environment became a place of interaction and not simply a repository for course materials as advocated in much of the literature on blended learning going back to Mason's early work in this field (1998). Videos and online lectures became a crucial element of the course, particularly in familiarising students with practices of self-access and autonomous investigation. From a language learning perspective, this also helped facilitate listening skills and improve practice at home. Added to this, some lessons were 'flipped' in that students had to listen to a short lecture or read a short text prior to the lesson and come to class ready to discuss the material. In this way, students were mirroring and adopting broader practices expected in specific disciplines within the UK higher educational environment.

\section{Case study of perceived effectiveness of the course}

Creswell defines any case study as 'a strategy of enquiry' which involves an in-depth exploration 'using a variety of data collection procedures over a sustained period' (2009, p.13) which must be framed in a 'bounded system' of time and activity (Stake, 1978). There are few systems of activity within higher education as bounded or intensive as a Pre-sessional course. In this case, the number of participants in the course afforded us the opportunity for an extensive amount of both quantitative and qualitative data through which the perceived effectiveness of the course could be measured.

That information was gained in different ways. The student perspective was gathered from two sources. Firstly, general feedback was collected in the form of responses to a set of questions on a Survey Monkey platform at both mid and end points on the Pre-sessional courses. Secondly, an important form of triangulation was attained through students being invited to respond to a further research study that I was doing in conjunction with a researcher from another university, relating to international students' perspectives on 
effectiveness of EAP courses. Through these outlets, a considerable amount of information was collected that provided valuable perspectives and insights on the student voice, but for the purposes of this paper it seems best to look at the course through the eyes of teachers. This is because there were less than twenty teachers as opposed to over two hundred students and the information generated from direct interviews with teachers, as native speakers, could be considered more trustworthy in this situation.

Responses from the teachers were gathered by means of focus group sessions and individual interviews. That was done in a semi-structured manner in the style stipulated by Borg (2006, p.190) where the scope of our discussion was flexible on account of being 'directed by a set of general themes, rather than specific questions'. This meant that I allowed for conversational exchanges that were professional and serious at the same time (Borg, 2006). The aim was 'to generate plausible accounts' (Silverman, 2005, p.154) rather than steering teachers towards a focus determined by me and not them. These discussions were further triangulated by conversations during the teacher induction and written feedback at the end of the course.

\section{Main areas of response from the teachers}

Lea and Street (1998, p.163) suggest that successful lecturers (in teaching through academic literacies approaches) are those that 'have spent many years of constructing their own knowledge through their own writing practices in a variety of disciplinary contexts'. Yet, in EAP, Alexander (2010, pp.3-5) aptly describes a situation where people are often recruited at short notice out of necessity rather than qualification. Some of these teachers find themselves making a leap from General English teaching to Academic English without any formal training and possibly too the absence of thorough academic inductions (Alexander, 2010, p.4). That lack of formal teacher education in EAP and understanding of discipline-specificity was apparent in feedback, focus group sessions and individual interviews with the teachers in this case.

One such respondent echoed a common refrain of 'but I don't know about the students' disciplines'. Several of the respondents primarily saw themselves as English teachers knowing what is best for the students in what Pierson and Borthwick (2010, p.130) 
describe as 'the thick of classroom practice.' This comes from a tradition within English Language Teaching of giving primacy to affective factors (Tomlinson, 2012) rather than focusing on academic aspects. The knowledge base of English teachers is shaped by methodologies that are reactive and responsive to immediate student needs and in discussions it was obvious that teachers saw the most pressing need as being remedial.

A typical argument was that these students 'need basic language skills' otherwise we are actually making them more peripheral to the life of the academy and doing the opposite of empowerment through giving them an academic identity. Because of the perceived 'cash cow' nature of the Pre-sessionals, these students were seen as having such low levels of English that they were not always viewed as being capable of achieving higher levels of 'knowledge telling, transformation and creation' as described by Gimenez and Thomas (2015, pp.29-32). Others felt that it is our job to teach them' and to give them strategies for learning that they then go and use in their actual disciplines'. However, for various reasons, some teachers felt that this was fine in theory, but not in practice.

One teacher with considerable experience in IELTS examining argued very strongly that 'these students are simply not at the required level' to acquire an objective of academic literacy that entails a deeper understanding of the meta-language of academic discourse and social practices in their disciplines. In saying this he is echoing an admission by Wingate and Tribble (2012, p.484) that applications of Academic Literacy theory seem to best exist in 'rather privileged contexts.' This line of thinking fed into a further argument that 'if we are testing them in a way that is benchmarked to IELTS, then why are we not teaching them what they need for those assessments.' Most emphatically, there was an assertion that 'what they need is General English.' Teachers seemed to be diagnosing the students as suffering what Lea and Street describe as a 'pathology of problems' (1998, p.159) shaped by another teacher's definition of 'the level (of student) we're getting.'

There were further issues that revealed themselves more subtly such as teachers' discomfort with the practice of discipline-specific EAP teaching. Student feedback simultaneously confirmed that many teachers interpreted discipline-specificity as the content of the texts students were given. For example, if given a reading related to Law, teachers perceived the discipline focus to be upon that particular subject to the extent that one said 'this is useless when I don't have any Law students in my class'. Another spoke 
of a political lecture being out of date because it was talking about the run up to Britain's 2016 referendum on membership of the European Union. At the same time, in a follow up to these comments, other respondents showed more awareness of the purpose of working with such texts. One experienced teacher argued that 'the focus isn't Brexit - it's teaching them to listen to a lecture' whilst a newer recruit to an EAP context pertinently stated that 'it's about giving them strategies to listen to an academic lecture like they'll have to do in their studies, no matter what the topic is.'

From some of the teachers then, I got a sense of failure to grasp the purpose of texts and materials. The disciplinary aspect is introduced by helping students to link the text and the subject to similar areas of their specific studies. Unfortunately, not all teachers seemed to be getting that and this message was also coming through in the views of students. For me though I could see the need to move beyond an approach that was based upon what might be described as talk around texts. This suggested that the next stage of developing this Pre-sessional was to move it beyond a focus on remedial language work towards a greater integration of disciplinary practices.

\section{Developing teachers to meet the course needs}

Stevick (1996, p.180) makes the vital point that the teacher remains the central chess piece around which any class is built and this is particularly true of a course intensive and demanding as a 23 hour per week Pre-sessional. Feedback revealed that teachers were very happy with the resources whether print-based or technological, with the curriculum and with the assessment - except in one case where the latter was described as 'too academic'. However, there remained a feeling amongst some teachers that it was difficult to understand precise definitions of academic literacy and discipline specificity. They could see what the theory suggested but some, even the more experienced, struggled to enact that as classroom theory-in-action - echoing the concerns of Argyris and Schön (1974) and Donaghue (2003).

I thus identified a need to better prepare teachers for the demands of an intensive Presessional course shaped around an academic literacies model. This began with the formulation of a 'Teachers' Guide' focusing as much on pedagogic strategy as on the 
traditional approach of questions and answers. Following on from this, inductions became more detailed, offering a clear pedagogy to support the ideology of academic literacies - a shift away from a knowledge base of communicative language teaching epistemologies towards greater emphasis on the role of what Shulman (1986) recurringly refers to as strategic knowledge within pedagogy. Despite being successful for most, these ideas were challenging for some. For example, in the second week of teaching, one less experienced teacher was still reaching for the tried and tested photocopies from an IELTS textbook, rather than using the official resources in the study pack of materials provided. However, with some mentoring and advice, this teacher gradually came to understand.

On the whole, teachers' acquisition of a suitable knowledge base for this pedagogic approach did not happen overnight. This supports a long-held belief in the field of teacher education that development cannot be limited to a one-off workshop formula (DarlingHammond and Richardson, 2009; McGrath et al, 2011, Breen, 2018). In a 2013 paper, I use the analogy of teacher education involving a deep process of intramuscular injection rather than a single shot with a syringe (Breen, 2013). This is particularly true in the context of familiarising EAP teachers operating on 'the margins of academia' (Ding and Bruce, 2017) with the social practices and diverse disciplines of higher education.

However, without doing this, it is impossible for those on said margins to develop the 'academic world view' advocated by Lea and Street (1998, p.163). It is also difficult for them to move away from a skills based deficit model/atomised skills approach to teaching (Lea and Street, 1998, p.157) unless they have an alternative pedagogy in place that makes sense of their practice. As one teacher stated in the aftermath of the course 'maybe you need to know what happens at the end before you make sense of why you need to do things' on an everyday basis. This particular teacher was a good example of somebody reluctant at first to make Kirk's (2012) definition of the 'leap' away from General English teaching into teaching English for Academic Purposes. However, by the end, and particularly after assessment results, this teacher understood the demands of the course and came to realise that 'I'm not actually helping students even though I thought that was what I was doing' by substituting academic content for materials deemed more engaging. 


\section{Conclusion}

On the whole then, teacher preparation seems to be an essential element in the delivery of courses such as this. As shown throughout this paper, the Pre-sessional course that I have described remains a work in progress. There have been elements of academic literacy introduced across a range of areas and teachers have a better, if not yet perfect, understanding of discipline-specificity. Awareness of that is essential if teachers are to move towards the levels aspired to by theorists such as Wingate (2012) or Gimenez and Thomas (2015). Teaching academic literacies requires an 'academic world view' according to Lea and Street (1998, p.163). Such a view is often difficult to conceptualise for those teachers who operate on the margins of academia and are often 'in service of the larger academic community' (Raimes, 1991, p.243) rather than active participants in disciplinary communities. Therefore, this study has not just identified pedagogic needs but also a greater need for EAP practitioners to be a part of the mainstream disciplinary communities they integrate students into. This does not just mean knowledge of disciplines themselves but strategic awareness of helping students navigate the practices of those disciplines. EAP and academic literacies work well in partnership when teachers are equipped with the knowledge, strategies, and confidence to put the values of each 'partner' into practice on an everyday basis.

\section{References}

Alexander, O. (2010) 'The leap into TEAP: the role of the BALEAP competency framework in the professional development of new EAP teachers'. Joint conference IATEFL English for Specific Purposes SIG, Bilkent University School of English Language Faculty Academic English Program, Bilkent University, Ankara, Turkey 18-19 June 2010 [online] Available at: http://www.uefap.com/baleap/teap/oa bilkent.pdf (Accessed: 3 November 2019).

Alexander, O., Argent, S. and Spencer, J. (2008) EAP Essentials: a teacher's guide to principles and practice. Reading: Garnet Publishing.

Argyris, C., and Schön, D. A. (1974) Theory in practice: increasing professional effectiveness. San Francisco, CA: Jossey-Bass. 
Blue, G. M. (1988) ‘Individualising academic writing tuition', in Robinson, P, (ed.) Academic writing: process and product. Oxford: Modern English Publications.

Borg, S. (2006) Teacher cognition and language education: research and practice. London: Continuum.

Breen, P. (2013) 'An intramuscular approach to teacher development in the field of transnational higher education' in Mukjeri, S. and Tripathi, P. (eds.) Handbook of Research on Transnational Higher Education Management. Hershey, PA: IGI Global, pp. 317-341.

Breen, P. (2018) Developing educators for the digital age - a framework for capturing teacher knowledge in action. London: Westminster University Press.

Coiro, J., Knobel, M., Lankshear, C. and Leu, D.J. (2008) 'Central issues in new literacies and new literacies research' in Coiro, J., Knobel, M., Lankshear, C. and Leu, D.J. (eds.) Handbook of research on new literacies. .New York: Routledge. pp.1-21.

Creswell, J. (2009) Research Design - Qualitative, Quantitative, and Mixed Methods Approaches. London: SAGE.

Darling-Hammond L., and Richardson, N. (2009) 'Teacher learning: what matters?' Educational Leadership, 66(5), pp. 46-53.

Ding, A. and Bruce, I. (2017) The English for Academic Purposes practitioner operating on the edge of academia. Cham, Switzerland: Palgrave Macmillan.

Donaghue, H. (2003) 'An instrument to elicit teachers' beliefs and assumptions.' $E L T$ Journal, 57(4), pp. 344-351.

Fink, L.D. (2007) 'The power of course design to increase student engagement and learning', Peer Review, 9(1), pp.13-17. 
Gilbert, J. (2013) 'English for academic purposes', in Motteram, G. (ed.) Innovations in learning technologies for English language teaching. London: British Council, pp. 117-144.

Gimenez, J. and Thomas, P. (2015) 'A framework for usable pedagogy: case studies towards criticality, accessibility and visibility', in Lillis, T., Harrington, K., Lea, M. and Mitchell, S. (eds.) Working with academic literacies: case studies towards transformative practice, Anderson, SC: Parlor Press, pp. 29-44.

Healy, P. (2014) 'The baby in the bathwater: a discussion of the role of motivation in teaching tertiary level students'. In Breen, P. Cases on teacher identity, cognition, and diversity in higher education. Hershey, PA: IGI Global, pp. 371-389.

Hyland, K and Hamp-Lyons, L. (2002) 'EAP: issues and directions', Journal of English for Academic Purposes, 1(1), pp. 1-12.

Jones, S., and Lea, M. R. (2008) 'Digital literacies in the lives of undergraduate students: exploring personal and curricular spheres of practice', Electronic Journal of Elearning, 6(3), pp. 207-216.

Kirk, S. (2012, December 9) Building e-AP Awareness. [Blog post] Available at: https://theteapingpoint.wordpress.com/2012/12/09/building-e-ap-awareness/ Accessed: 3 November 2019.

Koehler, M., and Mishra, P. (2009) 'What is technological pedagogical content knowledge (TPACK)?' Contemporary Issues in Technology and Teacher Education, 9(1), pp. 60-70.

Kress, G. (2000) 'Multimodality', in Cope, B and Kalantzis, M. (eds.), Multiliteracies. Literacy, learning and the design of social futures. London: Routledge, pp. 182-202.

Lea, M.R. and Street, B.V. (1998) 'Student writing in higher education: An academic literacies approach', Studies in higher education, 23(2), pp. 157-172. 
Lea, M.R. (2004) 'Academic literacies: a pedagogy for course design', Studies in higher education, 29(6), pp.739-756.

Lillis, T. (2003) 'Student writing as' academic literacies': drawing on Bakhtin to move from critique to design', Language and education, 17(3), pp.192-207.

Lillis, T. and Scott, M. (2007) 'Defining academic literacies research: issues of epistemology, ideology and strategy', Journal of applied linguistics, 4(1), pp. 5-32.

McGrath, J., Karabas, G., and Willis, J. (2011) 'From TPACK concept to TPACK practice: an analysis of the suitability and usefulness of the concept as a guide in the real world of teacher development', International Journal of Technology in Teaching and Learning, 7(1), pp. 1-23.

Mason, R. (1998) 'Models of online courses', ALN magazine, 2(2), pp. 1-10.

Pierson, M., and Borthwick, A. (2010) 'Framing the assessment of educational technology professional development in a culture of learning', Journal of Computing in Teacher Education, 26(4), pp. 126-131.

Raimes, A. (1991) 'Out of the woods: emerging traditions in the teaching of writing', TESOL quarterly, 25(3), pp. 407-430.

Shulman, L. (1986) 'Those who understand: knowledge growth in teaching', Educational Researcher, 15(24), pp. 4-14.

Silverman, D. (2005) Doing qualitative research: A practical handbook. London: SAGE Publications Limited.

Stake, R. E. (1978) 'The case study method in social inquiry', Educational Researcher, $7(2)$, pp. $5-8$

Stevick, E. W. (1996) Memory, meaning and method. Boston, MA: Heinle and Heinle. 
Tomlinson, B. (2012) 'Materials development for language learning and teaching', Language Teaching, 45(02), pp.143-179.

Turner, J. (2004) 'Language as academic purpose', Journal of English for Academic Purposes, 3(2), pp.95-109.

Wiggins, G. and McTighe, J. (2005) Understanding by design. Alexandria, VA: Association for Supervision and Curriculum Development

Wingate, U. (2012) 'Using academic literacies and genre-based models for academic writing instruction: a 'literacy journey', Journal of English for Academic Purposes, 11(1), pp.26-37.

Wingate, U. and Tribble, C. (2012) 'The best of both worlds? Towards an English for Academic Purposes/academic literacies writing pedagogy', Studies in Higher Education, 37(4), pp.481-495.

\section{Appendix one: sample extracts from the curriculum}

Sample from week one:

\begin{tabular}{|c|c|c|c|}
\hline Thursday & $\begin{array}{l}\text { Listening-predictions } \\
\text { and main ideas in a short } \\
\text { text; to develop fluency } \\
\text { in a discussion of the } \\
\text { topic of education }\end{array}$ & $\begin{array}{l}\text { Students will listen to a } \\
\text { TED talk in short extracts } \\
\text { and answer questions on } \\
\text { gist and ideas; students } \\
\text { will summarise the } \\
\text { lecture and share ideas } \\
\text { to practice fluency }\end{array}$ & Study Pack pp 39-44 \\
\hline Friday & $\begin{array}{l}\text { Students will prepare } \\
\text { and delivery an } \\
\text { individual mini } \\
\text { presentation about their } \\
\text { discipline to each other } \\
\text { in small groups - what it } \\
\text { is and why they have } \\
\text { chosen it; to practice } \\
\text { giving peer feedback; and } \\
\text { to practice the grammar } \\
\text { of asking questions }\end{array}$ & $\begin{array}{l}\text { Students prepare and } \\
\text { give presentations } \\
\text { Peer feedback on } \\
\text { performance } \\
\text { Self-evaluation of } \\
\text { performance } \\
\text { Grammar of questions }\end{array}$ & Study Pack pp 45-48 \\
\hline
\end{tabular}

Sample from week four: 


\begin{tabular}{|c|c|c|c|}
\hline Wednesday & \multicolumn{3}{|c|}{$\begin{array}{l}\text { Meet ss at Regent street reception to accompany them to Museum. You do not have to } \\
\text { walk around the museum with the ss unless you wish to! } \\
\text { FIELD TRIP TO THE BRITISH MUSEUM. } \\
\text { Study Pack pp } 173-176\end{array}$} \\
\hline Thursday & $\begin{array}{l}\text { Focus on scaffolding an } \\
\text { essay and the writing of } \\
\text { introductions and } \\
\text { conclusions. } \\
\text { (this is basic as it will } \\
\text { revised and extended for } \\
\text { research essays in } 7 \\
\text { week course) }\end{array}$ & $\begin{array}{l}\text { Overview of introductory } \\
\text { and concluding } \\
\text { paragraphs alongside } \\
\text { work on topic sentences, } \\
\text { thesis statements, unity, } \\
\text { coherence and cohesion. } \\
\text { Samples and exercises } \\
\text { related to this. }\end{array}$ & $\begin{array}{l}\text { HOMEWORK: READING } \\
\text { TEXT }\end{array}$ \\
\hline Friday & $\begin{array}{l}\text { Constructing a longer } \\
\text { piece of writing and } \\
\text { completion of timed } \\
\text { writing exercise. }\end{array}$ & $\begin{array}{l}\text { Watching video debate } \\
\text { between two academics. } \\
\text { Students will do the } \\
\text { timed writing relating to } \\
\text { the British Museum trip } \\
\text { using the text and notes }\end{array}$ & $\begin{array}{l}\text { Video of two academics on BB } \\
\text { SP pp } 184-190 \\
\text { TIMED WRITING TASK - } \\
\text { teachers will correct these at } \\
\text { home using corr code and } \\
\text { focusing on what covered so } \\
\text { far in course }\end{array}$ \\
\hline
\end{tabular}

\section{Author details}

Paul Breen is a Senior Lecturer in the University of Westminster's Centre for Education, Teaching and Innovation. His research interests are in academic literacies, teacher education and teacher knowledge. He is the author of several academic book publications including Developing Educators for the Digital Age, published by University of Westminster Press and most recently Professional Writing - How to Write Professionally and Successfully, published as part of the Studymates series. 